\title{
A COMPARATIVE STUDY OF LANGUAGE LEARNING STRATEGIES USED BY MONOLINGUAL AND BILINGUAL EFL LEARNERS
}

\author{
Moira Kostić-Bobanović, PhD. \\ University Juraj Dobrila of Pula \\ Department of Economics and Tourism \\ "Dr. Mijo Mirković" Pula (Croatia) \\ Department of Foreign Languages, Head \\ e-mail: moira.bobanovic@efpu.hr \\ Mieta Bobanović \\ University of Zagreb \\ Business School of Economics \\ e-mail: mietabb55@hotmail.com
}

\begin{abstract}
A b s tract
This paper addresses the difference in use of language learning strategies between bilingual and monolingual English as foreign language learners (EFL).

The study was conducted among 42 monolingual Croatian and 42 bilingual students of the University of Pula who are studying English as a foreign language. The data were analyzed by using the t-test. The results of the research suggested that bilingual students reported higher usage of learning strategies than their monolingual colleges with memory and metacognitive strategies reaching statistically significant level.

The findings of this study led to some suggestions to enhance students' use of learning strategies, increase their vocabulary size, and subsequently improve their English learning.
\end{abstract}

Key words: Language learning strategies, monolingual, bilingual, English as a foreign language

\section{Introduction}

For the last few decades, the researchers have been trying to find out the factors or variables affecting the foreign language learning. The researchers have also been interested in the distinguishment between successful learners and less successful learners. Since success is seen as the result of some variables, researchers (Ellis, 1985; McLaughlin 1987; Oxford, 1990, Shen, 2005) stressed that learning strategy use is one of the significant variables affecting language learning. 
Rubin (1975), Stern (1975), Naiman et al. (1978) and Skehan (1991) were one of the first researchers who suggested that information processing strategies are important in language learning and that these strategies can be learned by others who have not discovered them on their own. Research further demonstrated that good learners have an active involvement in language learning, that they have clear ideas and objectives, that they apply learning strategies while learning a second language and that these strategies can be described and classified (Rubin 1975; Naiman et al. 1978; Bialystok and Mayumder 1988; O'Malley et al. 1985; Chamot 1987; O'Malley and Chamot 1990; Bremner 1998; Ehrman et. al. 2003).

The term language learning strategy has been defined by many researchers. Wenden and Rubin (1987:19) define learning strategies as "any sets of operations, steps, plans, routines used by the learner to facilitate the obtaining, storage, retrieval, and use of information".

According to Oxford (1990) learning strategies are "specific actions taken by the learner to make learning easier, faster, more enjoyable, more self-directed, more effective, and more transferable to new situations" (p. 8). She emphasized that learning strategies are important for language learning because they are tools for active, selfdirected involvement making learning strategies a crucial element of the learning process.

Oxford (1990) sees the aim of language learning strategies as being oriented towards the development of communicative competence.

According to Wardough (1998), in this world, speaking more than one language is just a normal requirement of the daily life and it's not easy to find pure monolinguals. Following that perspective, it is important to investigate studies exploring the relationship between bilingualism and multilingualism and various factors like intelligence, cognitive development, learning styles and strategies.

Having had more experience with language learning through exposure to and acquisition of more than one language, multilinguals or bilinguals may have certain skills, strategies, or beliefs that enable them to approach the process of language learning more efficiently than people with experience in only one language (McLaughlin and Nayak, 1990).

Therefore, it can be stated that there is a meaningful difference in terms of the use of language learning strategies between monolingual and bilingual students. Showing this study as evidence, it can be claimed that there is a positive correlation between the strategy use and bilingualism. Wharton (2000) stated that bilinguals' use of strategies has been reinforced by previous success at acquiring or learning other languages.

Although there is much anecdotal evidence that people who have previously learned many languages are better at language learning than are "linguistically naïve subjects", there is very little empirical research on this topic (Nayak, et al., 1990, p.228). People with multiple language skills have been generally assumed to be individuals with notable facility in language learning (Rubin, 1975; Stern, 1975; Ramsay 1980; Garcia 2005). As Ramsay (1980) put it, such expectations are based upon the hypothesis that when learning a new language, adults will "approach tasks with strategies and behaviour that they consider productive, and these strategies will be drawn from past experience" (p. 90). Nation and McLaughlin (1986) suggested multilingual subjects habitually exert 
more processing effort in making sense of verbal stimuli than do monolingual subjects, and this can account for the superior performance of bilinguals. McLaughlin and Nayak (1990) find that multilingual participants are more flexible in their use of language learning strategies than their monolingual counterparts; the multilingual participants are more willing to change strategy if it is found to be ineffective. This study found that bilinguals had a greater facility for learning a third language, were more flexible in seeking and utilizing strategies appropriate to the task, and knew more readily than monolinguals which learning approach would work best for them in different language learning situations. Nayak et al. (1990) concluded that in the long run, multilinguals can be expected to outperform monolinguals during language learning because of their superior ability to shift strategies and restructure their internal representations of the linguistic system. Beyond these studies there is a little additional empirical research that proves advanced expertise of the bilingual and multilingual over monolingual learners.

\section{The Study}

Aim

The investigations about the use of language learning strategies have generally been conducted in countries where English is the official language. However, not many studies have been conducted about the use of learning strategies in other countries where bi- or multilingual speakers are available. In addition, limited studies on contrasting language learning behaviours and thoughts of monolingual and bilingual learners are available. Due to the fact that a great number of students who are attending University of Pula are bilingual EFL learners, there is a need for current information on how instruction in English is best facilitated for monolingual and bilingual group of learners. The aim of this study was to explore language learning strategy use of these two groups of students currently engaged in learning English as a foreign language.

We wanted to investigate the following questions: use?

1. What language learning strategies do monolingual and bilingual EFL learners

2. Is there a difference in the use of language learning strategies between the groups?

\section{Method}

\section{Participants}

The students from both groups were undergraduate students at the University of Pula studying English as a foreign language.

The first group of participants comprised 42 undergraduate students. Their first, acquired language was Croatian. None of the participants were fluent or able to communicate consistently and accurately in any language other than Croatian. Thus, they are best described as monolingual with some experience in academic foreign 
language instruction. The monolingual Croatian group was balanced in terms of gender with 21 males $(50 \%)$ and 21 females $(50 \%)$.

The second group comprised 42 bilingual university students. The bilingual students were 20 males (43\%) and 22 females (57\%). Members of bilingual group were students with the knowledge of two languages (Croatian and additional one; in this study our participants had knowledge of Albanian, German, Italian and Slovenian) Bilingual students used both Croatian and additional language on a daily basis in and out of school.

Table 1: Characteristics of Monolingual (N=42) and Bilingual (N=42) Participants

\begin{tabular}{|l|c|c|}
\hline \multirow{2}{*}{ Language } & \multicolumn{2}{|c|}{ Number of learners } \\
\cline { 2 - 3 } & Male learners & Female learners \\
\hline Monolingual & & \\
\hline Croatian & 21 & 21 \\
\hline Bilingual & 20 & 22 \\
\hline Albanian and Croatian & 2 & \\
\hline German and Croatian & & 1 \\
\hline Italian and Croatian & 17 & 19 \\
\hline Slovenian and Croatian & 1 & 2 \\
\hline
\end{tabular}

\section{Instruments}

The use of language learning strategies for oral communication was assessed by means of a questionnaire developed by Kostić-Bobanović (2004). The 41-item instrument asked learners to report the frequency with which they used certain speaking language learning strategies. It consisted of six groups of strategies: memory, cognitive, compensation, metacognitive, affective and social.

Memory strategies help learners enter information in long-term memory and retrieve it when necessary to communicate (e.g., using imagery, sounds, or both to remember new words). These are measured by three items.

Cognitive strategies involve formation and revision of internal mental models (e.g., reasoning, analyzing, and summarizing). These are measured by seven items.

Compensation strategies are used to assist learners to overcome limitations in language learning (e.g., guessing, using clues, getting help, and using gesture and synonyms, using circumlocution). These are measured by seven items.

Metacognitive strategies are techniques involved organizing, centring and directing learning such as planning schedule, self-monitoring and evaluating, and setting goals help learners manage their learning. These are measured by nine items.

Affective strategies enable learners to control emotions and attitudes related to language learning (e.g., reducing anxiety, discussing one's feelings with others). These are measured by ten items. 
Social strategies involve interacting and cooperating with others in language learning (6 items), such as asking questions and asking for correction. These are measured by five items.

The questionnaire asked the respondent to indicate in a multiple-choice fashion, the frequency of use (almost always to almost never on a five-point scale) of a given strategy.

Cronbach's alpha for internal reliability of questionnaire was 0.64 .

\section{Results and discussion}

The results from the questionnaire were processed using SPSS for Windows (Statistical Package for Social Sciences). The data were analyzed by using the t-test. The frequencies of use for each group of the strategies are presented in the tables below.

Table 2: Use of memory strategies by monolingual and bilingual participants.

\begin{tabular}{|c|c|c|c|c|c|c|}
\hline MEMORY STRATEGIES & 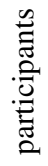 & $\mathrm{N}$ & M & SD & $\mathrm{t}$ & $\mathrm{p}$ \\
\hline \multirow{2}{*}{$\begin{array}{l}\text { 1. I put the new word in a sentence so } \\
\text { I can remember it }\end{array}$} & M & 42 & 3,19 & 1,02 & $-2,09$ & $\mathbf{0 , 0 3}$ \\
\hline & B & 42 & 4,05 & 1,72 & & \\
\hline \multirow{2}{*}{$\begin{array}{l}\text { 2. I remember a new English word and } \\
\text { an image or a picture of the word to } \\
\text { help me remember the word }\end{array}$} & M & 42 & 1,76 & 1,59 & $-0,26$ & 0,78 \\
\hline & B & 42 & 1,86 & 1,66 & & \\
\hline \multirow{2}{*}{$\begin{array}{l}\text { 3. When learning new material I } \\
\text { review often }\end{array}$} & $\mathrm{M}$ & 42 & 1,67 & 1,51 & $-1,05$ & 0,29 \\
\hline & B & 42 & 2,05 & 1,78 & & \\
\hline
\end{tabular}

According to data presented in the Table 2, bilingual participants were using memory strategies more than their monolingual peers. Statistically significant difference in using memory strategies among monolingual and bilingual students is noted for the strategy number 1: I put a new word in sentence so I can remember it $(\mathrm{t}=-2.09)$. Bilingual students reported statistically higher frequency of use of the above mentioned strategy. 
Table 3: Use of cognitive strategies by monolingual and bilingual participants.

\begin{tabular}{|c|c|c|c|c|c|c|}
\hline COGNITIVE STRATEGIES & 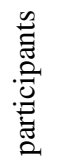 & $\mathrm{N}$ & M & SD & $\mathrm{t}$ & $\mathrm{p}$ \\
\hline \multirow{2}{*}{$\begin{array}{l}\text { 4. I practice my speaking skills by } \\
\text { repeating the new material }\end{array}$} & M & 42 & 3,67 & 1,59 & \multirow{2}{*}{1,49} & \multirow{2}{*}{0,14} \\
\hline & B & 42 & 4,24 & 1,91 & & \\
\hline \multirow{2}{*}{$\begin{array}{l}\text { 5. I recognize and use expressions in } \\
\text { English that are appropriate for the } \\
\text { situation. }\end{array}$} & M & 42 & 2,05 & 1,94 & \multirow{2}{*}{0,93} & \multirow{2}{*}{0,35} \\
\hline & $\mathrm{B}$ & 42 & 2,43 & 1,78 & & \\
\hline \multirow{2}{*}{$\begin{array}{l}\text { 6. I practice the sounds or alphabet of } \\
\text { English language. }\end{array}$} & M & 42 & 2,14 & 1,83 & \multirow[t]{2}{*}{0,00} & \multirow[t]{2}{*}{1,00} \\
\hline & B & 42 & 2,14 & 1,83 & & \\
\hline \multirow{2}{*}{$\begin{array}{l}\text { 7. I use familiar words in different } \\
\text { combinations to make new sentences. }\end{array}$} & M & 42 & 2,24 & 1,87 & \multirow{2}{*}{0,00} & \multirow{2}{*}{1,00} \\
\hline & $\mathrm{B}$ & 42 & 2,24 & 1,87 & & \\
\hline \multirow{2}{*}{$\begin{array}{l}\text { 8. I apply general rules to new } \\
\text { situations when using the English } \\
\text { language. }\end{array}$} & M & 42 & 1,19 & 1,31 & \multirow{2}{*}{1,18} & \multirow{2}{*}{0,24} \\
\hline & B & 42 & 1,48 & 0,86 & & \\
\hline \multirow{2}{*}{$\begin{array}{l}\text { 9. I translate from and onto my mother } \\
\text { tongue. }\end{array}$} & M & 42 & 2,52 & 1 & \multirow{2}{*}{1,75} & \multirow{2}{*}{0,08} \\
\hline & $\mathrm{B}$ & 42 & 3,29 & 1,97 & & \\
\hline \multirow{2}{*}{$\begin{array}{l}\text { 10. I use concepts and structures from } \\
\text { my mother tongue in English }\end{array}$} & M & 42 & 1,48 & 1,31 & \multirow{2}{*}{$-0,32$} & \multirow{2}{*}{0,75} \\
\hline & B & 42 & 1,57 & 1,42 & & \\
\hline
\end{tabular}

Analyzing the results presented in Table 3 we conclude that there are no statistically significant differences in the use of cognitive strategies between bilingual and monolingual students. 
Table 4: Compensation strategies used in monolingual and bilingual participants.

\begin{tabular}{|c|c|c|c|c|c|c|}
\hline COMPENSATION STRATEGIES & 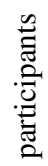 & $\mathrm{N}$ & M & SD & $\mathrm{t}$ & $\mathrm{p}$ \\
\hline \multirow{2}{*}{$\begin{array}{l}\text { 11. I use my mother tongue if I cannot think } \\
\text { of the right expression in English. }\end{array}$} & M & 42 & 3,19 & 1,02 & \multirow{2}{*}{$-0,43$} & \multirow{2}{*}{0,66} \\
\hline & B & 42 & 3 & 1,02 & & \\
\hline \multirow{2}{*}{$\begin{array}{l}\text { 12. I ask the other person to tell me the right } \\
\text { word if I cannot think of it in a } \\
\text { conversation. }\end{array}$} & M & 42 & 3 & 1,02 & \multirow{2}{*}{1,55} & \multirow{2}{*}{0,12} \\
\hline & B & 42 & 2,33 & 1,91 & & \\
\hline \multirow{2}{*}{$\begin{array}{l}\text { 13. If I am speaking and cannot think of the } \\
\text { right expression, I use gestures or mimics }\end{array}$} & M & 42 & 1,95 & 1,72 & \multirow{2}{*}{1,10} & \multirow{2}{*}{0,27} \\
\hline & B & 42 & 1,57 & 1,42 & & \\
\hline \multirow{2}{*}{$\begin{array}{l}\text { 14. I try to avoid the conversation if I don't } \\
\text { know the words to the subject }\end{array}$} & M & 42 & 1,1 & 0,62 & \multirow{2}{*}{0,00} & \multirow{2}{*}{1,00} \\
\hline & B & 42 & 1,1 & 0,62 & & \\
\hline \multirow{2}{*}{$\begin{array}{l}\text { 15. I direct the conversation to a topic for } \\
\text { which I know the words. }\end{array}$} & M & 42 & 2,05 & 1,78 & \multirow{2}{*}{0,00} & \multirow[b]{2}{*}{1,00} \\
\hline & B & 42 & 2,05 & 1,78 & & \\
\hline \multirow{2}{*}{$\begin{array}{l}\text { 16. I make up a new word if I do not know } \\
\text { the right one. }\end{array}$} & M & 42 & 1,76 & 1,59 & \multirow{2}{*}{1,62} & \multirow{2}{*}{0,10} \\
\hline & B & 42 & 1,29 & 1,04 & & \\
\hline \multirow{2}{*}{$\begin{array}{l}\text { 17. When I cannot think of the correct } \\
\text { expression to say or write, I find a different } \\
\text { way to express the idea, I use synonyms or } \\
\text { describe the idea. }\end{array}$} & M & 42 & 2,43 & 1,94 & \multirow[b]{2}{*}{0,69} & \multirow[b]{2}{*}{0,48} \\
\hline & B & 42 & 2,14 & 1,83 & & \\
\hline
\end{tabular}

The data about the use of compensation strategies are presented in Table 4. There are no statistically significant differences in the use of this group of strategies between bilingual and monolingual group.

The results for the use of metacognitive strategies are presented in the Table 5 . Bilingual participants have reported statistically significant higher usage of metacognitive strategy number 23: I carefully prepare and plan language tasks $(\mathrm{t}=-2.7)$ than their monolingual peers. 
Table 5: Metacognitive strategies use in monolingual and bilingual participants

\begin{tabular}{|c|c|c|c|c|c|c|}
\hline METACOGNITIVE STRATEGIES & 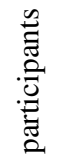 & $\mathrm{N}$ & M & SD & $\mathrm{t}$ & $\mathrm{P}$ \\
\hline \multirow{2}{*}{$\begin{array}{l}\text { 18. When learning English I try to } \\
\text { connect new and already learned } \\
\text { material. }\end{array}$} & M & 42 & 2,33 & 1,91 & \multirow{2}{*}{$-0,67$} & \multirow{2}{*}{0,5} \\
\hline & $\mathrm{B}$ & 42 & 2,22 & 1,99 & & \\
\hline \multirow{2}{*}{$\begin{array}{l}\text { 19. I decide in advance on which specific } \\
\text { language aspects I will pay special } \\
\text { attention to. }\end{array}$} & M & 42 & 3,57 & 1,94 & \multirow{2}{*}{$-1,45$} & \multirow{2}{*}{0,15} \\
\hline & $\mathrm{B}$ & 42 & 4,14 & 1,66 & & \\
\hline \multirow{2}{*}{$\begin{array}{l}\text { 20. I arrange my physical environment to } \\
\text { promote learning }\end{array}$} & M & 42 & 1,57 & 1,42 & \multirow{2}{*}{$-0,29$} & \multirow{2}{*}{0,76} \\
\hline & $\mathrm{B}$ & 42 & 1,67 & 1,51 & & \\
\hline \multirow{2}{*}{$\begin{array}{l}\text { 21. I plan my goals for English language } \\
\text { learning. }\end{array}$} & M & 42 & 1,48 & 1,31 & \multirow{2}{*}{0,34} & \multirow{2}{*}{0,72} \\
\hline & $\mathrm{B}$ & 42 & 1,38 & 1,19 & & \\
\hline \multirow{2}{*}{$\begin{array}{l}\text { 22. I have clear goals for improving my } \\
\text { English skills. }\end{array}$} & M & 42 & 1,38 & 1,19 & \multirow{2}{*}{$-0,66$} & \multirow{2}{*}{0,5} \\
\hline & $\mathrm{B}$ & 42 & 1,57 & 1,42 & & \\
\hline \multirow{2}{*}{$\begin{array}{l}\text { 23. I carefully prepare and plan language } \\
\text { tasks }\end{array}$} & M & 42 & 2,43 & 1,94 & \multirow{2}{*}{$-2,70$} & \multirow{2}{*}{$\mathbf{0 , 0 0}$} \\
\hline & B & 42 & 3,57 & 1,94 & & \\
\hline \multirow{2}{*}{$\begin{array}{l}\text { 24. I arrange my schedule to study and } \\
\text { practice the English language. }\end{array}$} & $\mathrm{M}$ & 42 & 1,48 & 1,31 & \multirow{2}{*}{0,34} & \multirow{2}{*}{0,72} \\
\hline & B & 42 & 1,38 & 1,19 & & \\
\hline \multirow{2}{*}{$\begin{array}{l}25 . \text { I am aware of my English mistakes } \\
\text { and try to correct them. }\end{array}$} & M & 42 & 1,52 & 1,42 & \multirow{2}{*}{0,32} & \multirow{2}{*}{0,75} \\
\hline & B & 42 & 1,48 & 1,31 & & \\
\hline \multirow{2}{*}{$\begin{array}{l}\text { 26. I think about my progress in learning } \\
\text { English. }\end{array}$} & M & 42 & 1,38 & 1,19 & \multirow{2}{*}{0,34} & \multirow{2}{*}{0,72} \\
\hline & B & 42 & 1,48 & 1,31 & & \\
\hline
\end{tabular}

From the results reported in Table 6, we noticed that there are no statistically significant differences among bilingual and monolingual students in the use of affective strategies. 
Table 6: Affective strategies use in monolingual and bilingual participants

\begin{tabular}{|c|c|c|c|c|c|c|}
\hline AFECTIVE STRATEGIES & 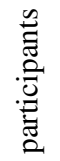 & $\mathrm{N}$ & M & SD & $\mathrm{t}$ & $\mathrm{p}$ \\
\hline \multirow{2}{*}{$\begin{array}{l}\text { 27. I try to relax my muscles breathing } \\
\text { deeply every time I feel nervous about } \\
\text { speaking }\end{array}$} & M & 42 & 1,1 & 0,62 & \multirow[t]{2}{*}{$-1,01$} & \multirow[t]{2}{*}{0,31} \\
\hline & B & 42 & 1,29 & 1,04 & & \\
\hline \multirow{2}{*}{ 28. I listen to music for relaxation. } & M & 42 & 2,43 & 1,94 & \multirow{2}{*}{0,93} & \multirow{2}{*}{0,35} \\
\hline & $\mathrm{B}$ & 42 & 2,05 & 1,78 & & \\
\hline \multirow{2}{*}{$\begin{array}{l}\text { 29. I laugh in order to relax, whenever I fell } \\
\text { nervous about speaking English }\end{array}$} & M & 42 & 1,38 & 1,19 & \multirow{2}{*}{0,39} & \multirow{2}{*}{0,69} \\
\hline & $\mathrm{B}$ & 42 & 1,29 & 1,04 & & \\
\hline \multirow{2}{*}{$\begin{array}{l}\text { 30. I make encouraging statements to } \\
\text { myself so that I will continue to try hard } \\
\text { and do my best in language learning. }\end{array}$} & M & 42 & 1,57 & 1,42 & \multirow{2}{*}{$-0,29$} & \multirow[b]{2}{*}{0,76} \\
\hline & B & 42 & 1,67 & 1,51 & & \\
\hline \multirow{2}{*}{$\begin{array}{l}\text { 31. I actively encourage myself to take wise } \\
\text { risks in language learning even though I } \\
\text { might make some mistakes. }\end{array}$} & M & 42 & 1,29 & 1,04 & \multirow{2}{*}{0,00} & \multirow{2}{*}{1,00} \\
\hline & B & 42 & 1,29 & 1,04 & & \\
\hline \multirow{2}{*}{$\begin{array}{l}\text { 32. I give myself a reward when I have } \\
\text { done something well in my language } \\
\text { learning. }\end{array}$} & M & 42 & 1,67 & 1,51 & \multirow{2}{*}{$-0,80$} & \multirow{2}{*}{0,42} \\
\hline & B & 42 & 1,95 & 1,72 & & \\
\hline \multirow{2}{*}{$\begin{array}{l}\text { 33. I pay attention to physical signs of } \\
\text { stress. }\end{array}$} & M & 42 & 1,19 & 0,86 & \multirow{2}{*}{$-1,18$} & \multirow{2}{*}{0,24} \\
\hline & B & 42 & 1,48 & 1,31 & & \\
\hline \multirow{2}{*}{$\begin{array}{l}\text { 34. I use a list in which I register my } \\
\text { feelings, motivation and attitudes about } \\
\text { English language learning }\end{array}$} & M & 42 & 1,38 & 1,19 & \multirow[t]{2}{*}{0,00} & \multirow[t]{2}{*}{1,00} \\
\hline & B & 42 & 1,31 & 1,19 & & \\
\hline \multirow{2}{*}{$\begin{array}{l}\text { 35. I write down my experiences in a } \\
\text { language learning diary. }\end{array}$} & $\mathrm{M}$ & 42 & 1,29 & 1,04 & \multirow{2}{*}{$-1,05$} & \multirow{2}{*}{0,29} \\
\hline & B & 42 & 1,57 & 1,42 & & \\
\hline \multirow{2}{*}{$\begin{array}{l}\text { 36. I talk to someone I trust about my } \\
\text { feelings concerning the language learning } \\
\text { process. }\end{array}$} & M & 42 & 1,19 & 0,86 & \multirow{2}{*}{0,00} & \multirow{2}{*}{1,00} \\
\hline & B & 42 & 1,19 & 0,86 & & \\
\hline
\end{tabular}

Analysing results given for the social strategies (Table 7) we can state that there are no statistically significant differences in the use of previously mentioned group of strategies among bilingual and monolingual group of participants.

The results of our study show a variety of learning strategies used by monolingual and bilingual students, with some strategies being used more frequently than others.

T-tests were computed to compare the use of each category of strategies between monolinguals and bilinguals, indicating a higher use of strategies by bilingual students. Bilinguals reported more frequent use of five categories of strategies: memory, cognitive, metacognitive, affective and social strategies. Compensation strategies are the 
only group of strategies monolinguals used more than bilinguals, even though the difference did not reach a significant level. Our results are similar to those presented in the study of Hong-Nam and Leavell (2007) in which monolingual students overcome bilingual students in the use of compensation strategies. We believe that monolingual students relied more heavily than bilinguals on compensation strategies to process information. The majority of monolingual students participating in our research reported frequently using mother tongue, gestures and mimics, synonyms, describing ideas or making up a new word when they cannot think of the right word in English.

Table 7: Use of social strategies in monolingual and bilingual participants.

\begin{tabular}{|c|c|c|c|c|c|c|}
\hline SOCIAL STRATEGIES & 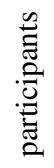 & $\mathrm{N}$ & M & $\mathrm{SD}$ & $\mathrm{t}$ & $\mathrm{p}$ \\
\hline \multirow{2}{*}{$\begin{array}{l}37 . \text { I ask other people to correct me when I } \\
\text { make mistakes while speaking. }\end{array}$} & $\mathrm{M}$ & 42 & 2,81 & 1,02 & \multirow{2}{*}{$-1,08$} & \multirow{2}{*}{0,28} \\
\hline & $\mathrm{B}$ & 42 & 3,29 & 1,00 & & \\
\hline \multirow{2}{*}{$\begin{array}{l}\text { 38. I work with other English language } \\
\text { learners. }\end{array}$} & $\mathrm{M}$ & 42 & 1,57 & 1,42 & \multirow{2}{*}{$-1,60$} & \multirow{2}{*}{0,11} \\
\hline & $\mathrm{B}$ & 42 & 2,14 & 1,83 & & \\
\hline \multirow{2}{*}{$\begin{array}{l}\text { 39. When I am talking with a native speaker, } \\
\text { I try to let him or her know when I need help. }\end{array}$} & $\mathrm{M}$ & 42 & 1,38 & 1,19 & \multirow{2}{*}{0,84} & \multirow{2}{*}{0,40} \\
\hline & B & 42 & 1,19 & 0,86 & & \\
\hline \multirow{2}{*}{$\begin{array}{l}\text { 40. I try to learn about the culture of the place } \\
\text { where the English language is spoken }\end{array}$} & $\mathrm{M}$ & 42 & 1,67 & 1,51 & \multirow{2}{*}{$-0,28$} & \multirow{2}{*}{0,77} \\
\hline & B & 42 & 1,76 & 1,59 & & \\
\hline \multirow{2}{*}{$\begin{array}{l}\text { 41. I pay close attention to the thoughts and } \\
\text { feelings of other people with whom I interact } \\
\text { in the English language. }\end{array}$} & $\mathrm{M}$ & 42 & 1,38 & 1,19 & \multirow{2}{*}{0,00} & \multirow{2}{*}{1,00} \\
\hline & $\mathrm{B}$ & 42 & 1,38 & 1,19 & & \\
\hline
\end{tabular}

As we mentioned before, bilinguals reported a higher use of strategies, but we have to emphasize that memory and metacognitive strategies are the strategies that bilinguals use more than monolingual students and the difference reached is at a statistically significant level.

Bilingual participants tend to favour visual strategies such as connecting the new English word to an image or picture, making a mental picture of a situation in which the word might be used. Interestingly, they were significantly more likely to review their English lessons than the monolingual students, again evidence of planning for their success and of the autonomous learning that is more characteristic of expert learners. Bilingual students participating in our study reported using metacognitive strategies to control learning such as: arranging physical environment to promote learning, thinking about their progress in learning English, seeking out ways to improve their learning, setting clear goals in learning English, and planning their schedule to study English.

This may signify that bilingual learners were more cognizant of the organization and time management necessary to learn a foreign language successfully because they have a better understanding of the real effort language learning requires. The higher- 
order executive skills that involve planning, organizing, monitoring, and evaluating (O'Malley and Chamot, 1990) are a characteristic of strategic learners and are often the most important difference between novice and expert learners (Paris, Lipson, and Wixson, 1994). According to Rivers (2001) the language learning expertise of the bilingual students allowed them to surpass monolinguals in self-regulated language learning, and to budget their time accordingly.

This reporting of greater strategy knowledge and use provides some support for the argument that bilinguals' exhibit advanced abilities when learning a new language as previous studies have indicated (Nation and McLaughlin, 1986; Thomas, 1988; Nayak et al., 1990).

\section{Conclusion}

The current study has presented empirical evidence of language learning differences between monolinguals and bilinguals in terms of learning strategy use. Monolingual and bilingual university students employed a wide variety of language learning strategies to learn English more effectively (memory, cognitive, compensational, metacognitive, affective and social) with bilingual learners employing, on average, more than their monolingual peers.

Bilingual students reported higher usage of learning strategies than their monolingual colleges with memory (Item 1) and metacognitive (Item 23) strategies reaching statistically significant level.

We may assume that bilinguals have higher skill and strategy levels for learning a new language or superior language learning abilities because of their dual language status. Studies on strategy use by monolingual and bilingual groups have reported more efficient use of learning strategies by bilingual students (Nation and McLaughlin, 1986), better language performance by bilinguals with formal training (Thomas, 1988), bilinguals outperforming monolinguals in learning rules for grammar (Nayak et al., 1990), and more capability for language learning in a self-paced, self-instructional format (Ramsay, 1980), indicating the same metacognitive superiority shown in this study. As previous studies on good language learners have stated, good language learners are aware of the various learning strategies available to them and tend to use more learning strategies (Rubin, 1975; Stern, 1975, Kostić-Bobanović, 2004; Parks and Raymond 2004). Higher strategy use may lead bilinguals to be more successful in learning languages than monolinguals.

The findings of the current study suggest that teachers should be aware of learners' strategy use to assist students to be good language learners.

\section{Bibliography}

Bialystok, E., and Majumder, S. (1988). The relationship between bilingualism and the development of cognitive processes in problem solving. Applied Psycholinguistics, 19, 69-85. 
Bremner, S. (1998). Language learning strategies and language proficiency: Investigating the relationship in Hong Kong. Asian Pacific Journal of Language in Education, 1, 490-514.

Chamot, A. (1987). The learning strategies of ESL students. In Wenden, A. \& Rubin, J. (Eds.). Learner strategies in language learning. (pp. 57-69). Prentice Hall: New Jersey.

Ehrman, M., Leaver, B. L., and Oxford, R. L. (2003). A brief overview of individual differences in second language learning. System, 31, 313-330.

Ellis, R. (1985). Understanding second language acquisition. Oxford: Oxford

Garcia, E. E. (2005). Teaching and learning in two languages: Bilingualism and schooling in the United States. New York: Teachers College Press.

Hong-Nam, K., \& Leavell, A. G. (2006). Language learning strategy use of ESL students in an intensive English learning context. System, 34, 399-415.

Kostić-Bobanović, M. (2004). Učinak poučavanja strategijâ učenja na razvijanje vještine govora u učenju engleskoga kao poslovnoga stranog jezika. Neobjavljena doktorska disertacija, Sveučilište u Zagrebu, Filozofski fakultet, Zagreb

McLaughlin, B. (1987). Theories of second-language learning. London: Edward Arnold.

Naiman, N., Frohlich, M., Stern, H. H., \& Todesco, A. (1978). The good Language learner. Toronto: Ontario Institute for Studies in Education.

Nation, R., and McLaughlin, B. (1986). Novices and experts: An information processing approach to the "good language learner" problem. Applied Psycholinguistics, 7, 41-56.

Nayak, N., Hansen, N., Krueger, N., and McLaughlin, B. (1990). Language-learning strategies in monolingual and multilingual adults. Language Learning, 40(2), 221-244.

O' Malley, J.M., Chamot, A.U., Stewner . Manzares, G., Russo, R.P., and Kupper, L. (1985). Learning strategy application with students of English as a second language. TESOL Quarterly, 19 (3), 557-584.

O'Malley, J. M., and Chamot, A.O. (1990). Learning strategies in second Language Acquisition. Cambridge: Cambridge University

Oxford, R. L. (1990). Language learning strategies: What every teacher should know. Boston: Heinle and Heinle, (pp. 5-35).

Paris, S., Lipson, M.Y., and Wixson, K.K. (1994). Becoming a strategic reader. In R. B. Rudell and H. Singer (Eds. 2nd ed.). Theroretical models and processes of reading (pp. 788-810). Newark, DE: International Reading Association.

Parks, S., and Raymond, P. (2004). Strategy use by nonnative-English- speaking students in an MBA program: Not business as usual! Modern Language Journal, 88(3), 374-389.

Ramsay, R. (1980). Language-learning approach styles of adult multilinguals and successful language learners. In V. Teller and S. White (Eds.). Students in child language and multilingualism (pp. 73-96). New York: New York Academy of Sciences.

Rivers, W. P. (2001). Autonomy at all costs: An ethnography of metacognitive self assessment and self-management among experienced language learners. The Modern Language Journal, 85(2), 279-290.

Rubin, J. (1975). What the "Good language Learner" can teach us? TESOL Quarterly, 9, 41-51.

Rubin, J. (1987). Learner strategies: Theoretical assumptions, research history and typology. In A. wenden, \& J. Rubin, (eds.). Learner strategies in language learning. Prentice Hall: New Jersey. (pp. 15-35).

Shen, H. (2005). An investigation of Chinese-character learning strategies among non-native speakers of Chinese. System, 33, 49-68.

Skehan, P. (1991). Individual differences in second language larning. Studies in Second Language Acquisition, 13, 275-298. 
Stern, H. H. (1975). What can we learn from the good language learner? Canadian Modern Language Review, 31, 304-318.

Thomas, J. (1988). The role played by metalinguistic awareness in second and third language learning. Journal of Multilingual and Multicultural Development, 9, 235-246. University Press.

Wardough, R. (1998). An introduction to sociolinguistics. 3rd Ed. Malden, MA: Blackwell.

Wenden, A., \& Rubin, J. (1987). Learner strategies in language learning. Englewood Cliffs, N.J.: Prentice Hall.

Wharton, G. (2000). Language learning strategy use of bilingual foreign Language learners in Singapore. Language Learning 50(2), 203-243.

Metodički obzori 6(2011)3 Izvorni znanstveni rad

UDK: 371.3:811.111'243]:378.4(497.5 Pula) Primljeno: 21. 6. 2010.

\section{ISTRAŽIVANJE STRATEGIJÂ UČENJA KOD JEDNOJEZIČNIH I DVOJEZIČNIH UČENIKA ENGLESKOGA KAO STRANOG JEZIKA}

Dr. sc. Moira Kostić-Bobanović, Sveučilište Jurja Dobrile u Puli, Odjel za ekonomiju i turizam "Dr. Mijo Mirković" Pula (Hrvatska) e-mail: moira.bobanovic@efpu.hr

Mieta Bobanović University of Zagreb Business school of Economics e-mail: mietabb55@hotmail.com

\section{Sa žetak}

Strategije učenja prema mnogim autorima predstavljaju značajnu varijablu usvajanja jezika (Ellis, 1985; McLaughlin 1987; Oxford, 1990, Shen, 2005), a nedavna istraživanja na ovom području započela su sa proučavanjem njihova razlikovanja između jednojezičnih i višejezičnih govornika.

Ovaj rad istražuje razlike u upotrebi strategijâ kod dvojezičnih i jednojezičnih govornika engleskoga kao stranog jezika.

Istraživanje je provedeno na uzorku od 42 jednojezična te 42 dvojezična učenika koji uče engleski kao strani jezik na Sveučilištu u Puli. Razlike u upotrebi strategija između dviju grupa provjerene su t-testom. Prema dobivenim rezultatima možemo zaključiti da dvojezični govornici više upotrebljavaju strategije učenja od svojih jednojezičnih vršnjaka, a razlike u upotrebi strategija pamćenja te metakognitivnih strategijâ su statistički značajne u korist dvojezičnih govornika.

Rezultati ovog istraživanja mogu pomoći učenicima stranih jezika pri učinkovitijoj uporabu strategija učenja.

Ključne riječi: strategije učenja jezika, jednojezični govornici, dvojezičani govornici, engleski kao strani jezik 